\title{
Leczenie żywieniowe u chorych na nowotwory piersi
}

\section{Nutritional support in patients with breast cancer}

\author{
Agata Lewandowska, Alicja Elżbieta Woźniak \\ Poradnia Leczenia Żywieniowego, Instytut Hematologii i Transfuzjologii, Warszawa
}

\begin{abstract}
Streszczenie
Nowotwory piersi sq najczestszymi nowotworami w populacji kobiet oraz druga po nowotworach płuc przyczyna zgonu spośród wszystkich chorób nowotworowych w tej grupie. Przebudowa tkanek gruczotu piersiowego, pojawiajace sie wielokrotne w ciagu życia - w okresie dojrzewania, podczas ciaz-sprzyjaja powstawaniu specyficznego środowiska, charakteryzujacego sie wzbudzona reakcja immunologiczna oraz sttumionym stanem zapalnym, które prawdopodobnie utatwia kancerogeneze. Do czynników przyczyniajacych sie do rozwoju nowotworów piersi należa zaburzenia równowagi hormonalnej, uwarunkowania genetyczne oraz czynniki środowiskowe ( $w$ tym nadwaga i niska aktywność fizycznej). Do tej pory nie opracowano wytycznych żywienia w okresie remisji nowotworów piersi, jednak specjaliści wskazuja, że ich podstawa powinny być zasady profilaktyki pierwotnej. Obecność choroby nowotworowej powoduje zmiane zapotrzebowania na sktadniki pokarmowe, ponadto konsekwencja leczenia sa zaburzenia jelitowe oraz zmniejszenie apetytu, co $w$ efekcie zwiększa ryzyko niedożywienia. Zmodyfikowany profil diety może pozytywnie wptywać na jakość zycia kobiet z nowotworami piersi, wydolność ich organizmu, a także potencjalnie na poprawe rokowania.
\end{abstract}

Słowa kluczowe: leczenie żywieniowe, dieta, suplementy diety, rak piersi, jakość życia

Hematologia 2017; 8, 3: 197-210

\begin{abstract}
In women, breast cancer is the most common malignancy whilst its morbidity rates are the second most frequent after lung cancer. Rearrangements of developmental changes in mammary gland tissue that occur many times throughout life (eg. during puberty, pregnancy), create a specific environment as demonstrated by an enhanced immune response but suppressed inflammatory status; these being most likely conducive to carcinogenesis. Contributing factors to breast cancer development include: endocrine disruption, genetic predisposition and environmental determinants such as overweight and low levels of physical activity. Hitherto, nutritional guidelines in cases of breast cancer remission are lacking, nevertheless specialists state that they should be based on primary prevention. The presence of cancer confers changes to dietary requirements, whilst the side effects of treatment are gastro-intestinal disorders and anorexia which lead to malnourishment. A modified diet may thus beneficially impact upon women's quality of life during breast cancer remission, together with potentially improving their survival prognoses.
\end{abstract}

Key words: nutritional support, diet, diet supplementation, breast cancer, quality of life

Hematologia 2017; 8, 3: 197-210

Adres do korespondencji: Agata Lewandowska, Poradnia Leczenia Żywieniowego, Instytut Hematologii i Transfuzjologii, ul. Indiry Gandhi 14, 02-776 Warszawa, tel. 223496 302, faks 223496 335, e-mail: alewandowska@ihit.waw.pl 


\section{Epidemiologia}

Nowotwory piersi są najczęstszymi nowotworami w populacji kobiet, gdzie stanowią $21,7 \%$ wszystkich przypadków (standaryzowany wspó1czynnik zachorowalności $-51,6 / 100$ tys. osób). Szczyt zachorowań notuje się między 55. a 64. rokiem życia, natomiast już po 35 . roku życia ryzyko zachorowania znacząco się zwiększa [1]. Zachorowalność na nowotwory piersi w Polsce jest niższa $w$ porównaniu $z$ danymi światowymi oraz średnią europejską, natomiast jest wyższa niż w Europie Środkowo-wschodniej. Wartość współczynnika zachorowalności na tym obszarze wynosi 47,7/100 tys. osób, a wyższą wartość niż w Polsce notuje się jedynie w Czechach, Bułgarii, Słowacji i na Węgrzech [2]. Tendencja umieralności na nowotwory piersi w Polsce jest obecnie w fazie spadkowej i według najnowszych danych wynosi 14,77/100 tys. osób. Wartość ta sytuuje nowotwory piersi na drugim miejscu wśród wszystkich nowotworowych przyczyn zgonów, stanowiąc 13,9\% $z$ nich (pierwsze miejsce stanowią nowotwory płuc - 17,2\%). Współczynnik umieralności określony dla danych ogólnoświatowych jest niższy niż w Polsce i wynosi 12,9/100 000 osób, a wyższy dla państw Europy Środkowo-wschodniej z wynikiem 16,5/100 tys. osób $[1,2]$.

\section{Etiologia}

Ponieważ gruczoły piersiowe rozwijają się w okresie dojrzewania oraz w trakcie każdej ciąży, wymagają odmiennego, zależnego od hormonów systemu regulacyjnego niż reszta organów, które rozwinęły się w okresie płodowym i niemowlęcym. W wyniku stymulacji takimi hormonami, jak: estrogen, progesteron, glukokortykosteroidy, prolaktyna, insulina, hormon wzrostu $(\mathrm{GH}$, growth hormone) czy insulinopodobny czynnik wzrostu 1 (IGF-1, insulin-like growth factor-1), proces rozwoju gruczołów nasila się, uwzględniając proliferację i różnicowanie komórek (np. nabłonka przewodów lub tanki łącznej) oraz wytwarzanie nowych naczyń krwionośnych czy reorganizację fibroblastów i adipocytów. Prawidłowy przebieg tych procesów wymaga także odmiennej regulacji immunologicznej, angażującej w tym celu między innymi makrofagi, eozynofile oraz mastocyty [3]. Także proces inwolucji, który jest obserwowany po zakończeniu karmienia piersią oraz w okresie menopauzy, wymaga nasilonej kontroli ze strony układu immunologicznego $z$ powodu intensywnie zachodzącego procesu apoptozy oraz przebudo- wy tkanek. Na podstawie analizy porównawczej ekspresji genów na poziomie transkryptu stwierdzono, że początkowa faza inwolucji wykazuje podobieństwo, między innymi na drodze aktywacji proteasomu, z reakcją ostrej fazy (APR, acute-phase response), która jest inicjowana w wywołanym urazem lub infekcją procesie gojenia tkanek [4]. Istotną różnicą jest jednak zahamowanie rozwoju stanu zapalnego w obrębie gruczołu piersiowego, aby nie dopuścić do szoku toksycznego oraz zapewnić bezpieczne usuwanie pozostałości mleka i fragmentów komórek (ciałek apoptotycznych) [5]. W tym celu komórki nabłonkowe uwalniają cytokiny o charakterze immunosupresyjnym już w fazie początkowej. Takie działanie pozwala między innymi zapobiegać wynaczynianiu neutrofili i nasilaniu lokalnego stanu zapalnego, co ogranicza równocześnie skuteczny nadzór immunologiczny, niezbędny do eliminacji zmienionych nowotworowo komórek. W kolejnej fazie inwolucji, poza neutrofilami, zaangażowane są także makrofagi i eozynofile. Co więcej, stwierdza się obecność znacznej ilości immunoglobulin oraz komórek plazmatycznych (głównie w fazie końcowej), których rola nie jest w pełni wyjaśniona, jednakże może służyć prewencji zakażenia [4]. Wydaje się, że specyficzne mikrośrodowisko gruczołów piersiowych, które powstaje $\mathrm{w}$ związku $\mathrm{z}$ procesem inwolucji, cechujące się zarazem wzbudzoną odpowiedzią immunologiczną oraz stłumionym stanem zapalnym, sprzyja także procesowi nowotworzenia. Konieczność wielokrotnej przebudowy tkanek gruczołu piersiowego powoduje, że wykazują one także niską immunogenność [niską ekspresję antygenów na główny układ zgodności tkankowej (MHC, major histocompatibility complex)], co w przypadku rozwoju nowotworu ogranicza możliwość rozpoznania zmutowanych komórek przez limfocyty $\mathrm{T}$ i B oraz może ograniczać efekt terapii celowanych molekularnie [5].

Steroidowe hormony płciowe - androgeny, estrogeny, progesterony — odgrywają jedną $z$ głównych ról w patogenezie nowotworów piersi [6]. Przyłączenie estrogenu do receptora estrogenowego (ER, estrogen receptor) stymuluje proliferacje komórek oraz promuje przeżycie zarówno komórek zdrowych, jak i nowotworowych. Efektem działania estrogenów jest nasilenie ekspresji genów, między innymi receptora dla insulinopodobnego czynnika wzrostu 1 (IGF-1R, insuline-like growth factor 1 receptor), antyapoptotycznego białka BCL2, receptora dla ludzkich naskórkowych czynników wzrostu (HER, human epidermal growth factor receptor) czy naczyniowego śródbłonkowego czynnika wzrostu (VEGF, vascular endothelial growth factor), które są 
ściśle związane z rozwojem zmian nowotworowych [7]. W prawidłowym nabłonku przewodów i zrazików zaledwie 7-10\% komórek wykazuje ekspresję receptorów dla hormonów steroidowych. Tymczasem jedną $z$ cech komórek nowotworowych jest nadmierna ekspresją tych receptorów, nawet w $75 \%$ zdiagnozowanych przypadków [8], co decyduje pośrednio o nasilonym potencjale do wzrostu guza [9]. Poprzez stymulację ER oraz prawdopodobnie od nasilenia ekspresji receptorów dla czynników wzrostu (głównie HER2 i IGF-1R) zależy także regulacja receptora dla progesteronu ( $\mathrm{PrG}$, progesterone receptor) w komórkach gruczołu piersiowego oraz narządów rodnych [10]. Progesteron, podobnie jak estrogen, jest niezbędny w okresie dojrzewania (do prawidłowego rozwoju gruczołów piersiowych) oraz przygotowania do laktacji. Stwierdzono, że wysokie stężenie estrogenu w kombinacji $z$ progesteronem $\mathrm{w}$ większym stopniu zwiększa ryzyko nowotworzenia niż obserwowane osobno [6]. Wzajemne odziaływanie między szlakami sygnałowymi receptorów dla estrogenu (i innych hormonów steroidowych) oraz czynników wzrostu jest obserwowane naturalnie w komórkach zdrowych. Tymczasem w komórkach nowotworowych, gdzie dochodzi do nadekspresji tych receptorów, postuluje się wzajemne nasilanie ich aktywacji i utratę zdolności regulacyjnych [8]. Folikulotropina (FSH, follicle-stimulating hormone) i lutropina ( $\mathrm{LH}$, luteinizing hormone) również pośrednio mogą wpływać na rozwój nowotworów gruczołu piersiowego. Oba hormony są odpowiedzialne za syntezę estrogenów: LH nasila wydzielanie androgenów przez jajnik, natomiast FSH stymuluje ich aromatyzację do estrogenów. W zmienionych nowotworowo komórkach gruczołu piersiowego zidentyfikowano receptory dla LH (LHR, luteinizing hormone receptore) oraz stwierdzono, że mogą one pośrednio pobudzać produkcję estrogenów wewnątrz guza [11].

Etiologia nowotworów piersi jest w większości przypadków nieznana, jednak wiedza na temat czynników ryzyka oraz mechanizmów kancerogenezy rośnie. Rozwój nowotworów piersi, podobnie jak innych typów nowotworów, jest zależny od działania czynników mutagennych, które uszkadzają cząsteczkę DNA, prowadząc do powstania mutacji w genomie prawidłowej komórki, jak i czynników mitogennych, sprzyjających mitotycznym podziałom komórkowym. Spośród tych pierwszych wymienić należy między innymi nadmiar wolnych rodników, promieniowanie jonizujące i UV, niektóre związki chemiczne, barwniki akrydynowe czy wirusy określane mianem onkogennych. Czynnikami mitogennymi mogą być natomiast niektóre hor- mony czy endotoksyny bakteryjne [12]. W tabeli 1 przedstawiono specyficzne dla nowotworów piersi czynniki ryzyka o udokumentowanym znaczeniu $[6,13]$. Uwzględniają one między innymi modyfikowalne elementy stylu życia czy niemodyfikowalne cechy fizjologiczne, których wpływ, szczególnie skojarzony, może prowadzić do zwiększenia stężeń wyżej wymienionych hormonów, zaburzenia regulacji hormonalnej i immunologicznej czy akumulacji substancji kancerogennych. Przykładowo, konsekwencją nadmiernej masy ciała oraz braku aktywności fizycznej jest rozwój insulinooporności, nasilenie procesu przekształcania androgenów do czynnych form estrogenów (aromatyzacja), który zachodzi w tkance tłuszczowej, wątrobie, nadnerczach, mięśniach i tkance gruczołowej piersi, jak równiė obniżenie syntezy białek transportowych dla tych hormonów w wątrobie. W efekcie stężenie estronu i estradiolu we krwi, które stanowią aktywne formy estrogenów, może się znacząco zwiększać [6]. Efekt ten jest większy u kobiet po menopauzie, ze względu na przekierowanie syntezy estrogenów tylko do obszarów pozagruczołowych oraz fizjologicznie niższą wrażliwość na insulinę. Udowodniono, że na zwiększenie produkcji estrogenu u kobiet po menopauzie wpływają otyłość, nadczynność tarczycy, marskość wątroby oraz kortykosteroidy [14], a im wyższa jest zawartość tkanki tłuszczowej w organizmie, tym produkcja estrogenów, stężenie insuliny i IGF-1 oraz stopień insulinooporności są wyższe, natomiast stężenie ochronnych adiponektyn — niższe [10, 15].

Zaburzenie równowagi hormonalnej w kierunku podwyższonego stężenia androgenów, estrogenów, FSH i LH, uwarunkowania genetyczne (obecność mutacji w genach predysponujących do rozwoju nowotworów piersi, np. BRCA 1 i 2, P53, MSH2), jak również wpływ czynników ryzyka stanowią elementy przyczyniające się do rozwoju nowotworów piersi [16]. W celu oceny ryzyka zachorowania proponuje się określanie: uwarunkowań patogenezy, podatności genetycznej, oceny gęstości mammograficznej oraz zmian histologicznych w przebiegu inwolucji gruczołu piersiowego [17]. Jednak ze względu na dużą heterogeniczność nowotworów piersi oraz nie w pełni poznaną patofizjologię, przewidywanie zachorowania jest ograniczone, na co wskazuje między innymi fakt, że u $70 \%$ kobiet chorych nie stwierdza się żadnego z czynników ryzyka [18].

\section{Diagnostyka i leczenie}

Diagnostyka raka piersi opiera się na klasyfikacji biologicznej (molekularnej), uwzględniającej 
Tabela 1. Czynniki ryzyka rozwoju nowotworów piersi (na podstawie $[6,13]$ )

Table 1. Risk factors of breast cancer (based on $[6,13]$ )

\begin{tabular}{|c|c|}
\hline Typ czynników & Czynniki ryzyka \\
\hline \multirow{7}{*}{$\begin{array}{l}\text { Hormonalne } \\
\text { i reproduktywne }\end{array}$} & Wczesny wiek pierwszej miesiączki \\
\hline & Późny wiek ostatniej miesiączki \\
\hline & Pierwsza donoszona ciąża w późnym wieku (po 30. rż.) \\
\hline & Brak ciąż \\
\hline & Stan po menopauzie \\
\hline & Stosowanie doustnej antykoncepcji \\
\hline & Stosowanie hormonalnej terapii zastępczej \\
\hline \multirow{7}{*}{$\begin{array}{l}\text { Związane z czynnikami } \\
\text { fizjologicznymi i stanem } \\
\text { zdrowia }\end{array}$} & Starszy wiek (wzrost ryzyka od 35. rż.) \\
\hline & Historia rodzinna raka piersi \\
\hline & Rak piersi, jajnika i trzonu macicy w przeszłości \\
\hline & Wystąpienie zmian łagodnych w piersiach, przebiegające z obecnością rozrostu atypowego \\
\hline & Promieniowanie jonizujące, stosowane w związku np. z terapią chłoniaka Hodgkina \\
\hline & Szybki wzrost w okresie dojrzewania i wysoki wzrost w dorosłym wieku \\
\hline & Zakażenie wirusem onkogennym (np. Epsteina-Barr) \\
\hline \multirow[t]{7}{*}{ Żywieniowe } & Dieta typu zachodniego \\
\hline & Nadmierne spożycie tłuszczów, szczególnie tłuszczów zwierzęcych \\
\hline & Wysokie spożycie mięsa czerwonego i smażonego \\
\hline & Wysokie spożycie żelaza \\
\hline & Rozwój nadwagi/otyłości po menopauzie \\
\hline & Niskie spożycie świeżych warzyw i owoców \\
\hline & Niskie spożycie fitoestrogenów (izoflawonów, lignanów) \\
\hline \multirow{3}{*}{$\begin{array}{l}\text { Inne związane } \\
\text { ze stylem życia }\end{array}$} & Regularne umiarkowane/wysokie spożycie alkoholu \\
\hline & Brak regularnej aktywności fizycznej \\
\hline & Praca w godzinach nocnych \\
\hline
\end{tabular}

typ histopatologiczny, ekspresję receptorów steroidowych (ER i PgR), ekspresję białka HER2 oraz indeks proliferacyjny mierzony dodatnią ekspresją antygenu Ki-67. Na tej podstawie wyróżnia się 5 podtypów raka piersi różniących się profilem molekularnym. Są to podtypy: luminalny A i B, podstawny (bazoidalny), $z$ nadekspresją HER2 $($ HER $2+)$ i podtyp $z$ ekspresją genów typowych dla komórek prawidłowego gruczołu piersiowego (normal breast-like) [6, 19]. Do głównych czynników rokowniczych należą: wielkość guza, typ histopatologiczny i stopień złośliwości (grading), liczba zajętych przerzutami węzłów chłonnych pachy, naciekanie naczyń chłonnych i żylnych w otoczeniu guza, stan ER, PgR, HER2 i wskaźnik proliferacji Ki-67 [20].

Leczenie nowotworów piersi uwzględnia postępowanie wielodyscyplinarne i skojarzone. Obejmuje zarówno stosowanie chemioterapeutyków, hormonoterapii, radioterapii, jak i leczenia operacyjnego i ukierunkowanego na cele molekularne.
Wybór metody leczenia ustalany jest na podstawie oceny stopnia klinicznego zaawansowania choroby oraz zdiagnozowanego podtypu. Dodatkowo na wybór terapii wpływają także ogólny stan zdrowia, w tym stan odżywienia, obecność chorób towarzyszących oraz przebyte uprzednio leczenie przeciwnowotworowe. Podstawową metodą terapii jest obecnie zabieg operacyjny obejmujący resekcję guza $\mathrm{z}$ odpowiednim marginesem oraz $\mathrm{w}$ sytuacji stwierdzenia przerzutów - usunięcie także węzłów chłonnych okolicy pachowej. Zastosowanie radioterapii jest uważane za terapię uzupełniającą po leczeniu chirurgicznym oraz jako metoda leczenia paliatywnego. Chemio-, hormono- lub immunoterapia są określane jako leczenie systemowe, które może być stosowane zarówno przed wykonanym zabiegiem operacyjnym, jak i po nim oraz w leczeniu paliatywnym [21]. Cytotstatyki są częstymi komponentami terapii przeciwnowotworowej, używanymi w celu redukcji ryzyka przerzutów odległych w innych narządach. Do 
najczęściej aplikowanych należą: doksorubicyna, cyklofosfamid, docetaksel, paklitaksel, kapecytabina, winorelbina, mitoksantron, metotreksat, cisplatyna. Hormonoterapia, której wybór opiera się na swoistych cechach molekularnych nowotworu danego pacjenta, co pozwala na indywidualizację terapii, jest stosowana $z$ zamiarem $z$ mniejszenia rozmiarów guza oraz zahamowania wzrostu zmienionych nowotworowo obszarów gruczołu, które są niewidoczne w badaniach diagnostycznych [13]. Spośród leków stosowanych w terapii hormonalnej nowotworów piersi wyróżnia się leki działające antagonistycznie (antyestrogeny, np. tamoksyfen), addytywnie (progestageny, np. octan megastrolu, octan medroksyprogesteronu) lub supresyjnie (analogi hormonu uwalniającego gonadotropiny oraz inhibitory aromatazy). Obecnie w postępowaniu przeciwnowotworowym, ze względu na niezadowalający profil tolerancji, praktycznie nie znajdują zastosowania inne leki hormonalne (estrogeny, androgeny), które kiedyś stanowiły podstawę hormonoterapii $\mathrm{w}$ raku piersi $[22,23]$. Leki nowszej generacji są natomiast bardziej swoiste i odznaczają się większą skutecznością w obniżeniu stężenia estrogenów oraz lepszą tolerancją. Wybór metody leczenia systemowego ściśle zależy od podtypu nowotworu i może uwzględniać tylko jedną $z$ nich, jak w przypadku podtypu luminalnego A, gdzie stosuje się głównie terapię hormonalną lub też łączyć kilka metod (np. podtyp luminalny B, HER2 +) [24]. U kobiet, które cechują się nadekspresją ER i PgR odpowiedź na leczenie hormonalne jest zwykle wysoka, natomiast jednocześnie stan ten ogranicza osiągnięcie efektu terapeutycznego chemioterapii [20]. Nowoczesne leczenie nowotworów piersi coraz częściej jest zindywidualizowane, co jednak nie zapobiega występowaniu licznych działań niepożądanych oraz zmian fizjologicznych, które powstają w związku $z$ rozpadem komórek nowotworowych. W konsekwencji terapia nowotworów piersi wymaga leczenia interdyscyplinarnego, uwzględniającego między innymi leczenie bólu, rehabilitację oraz leczenie żywieniowe, jak również stałej kontroli nawrotów oraz odległych zdarzeń niepożądanych.

\section{Interwencje żywieniowe związane $\mathrm{z}$ działaniami niepożądanymi leczenia}

Nowotwór złośliwy piersi najczęściej ma postać guza o słabo zarysowanych granicach, dlatego też proces napromieniania wymaga zachowania marginesu zdrowej tkanki. W momencie pochłonięcia dawki promieniowania jonizującego przez masę guzową oraz tkanki otaczające dochodzi do szeregu reakcji fizycznych i biochemicznych, które wywołują efekt kliniczny w postaci regresji guza, zwłóknienia tkanki zdrowej czy też w dłuższej perspektywie - wtórnego nowotworu popromiennego. Promieniowanie jonizujące, w wyniku destrukcyjnego działania na elementy składowe komórki, na przykład cząsteczki DNA, generuje zmiany w jej strukturze. Powstałe uszkodzenia mogą zostać naprawione lub są trwałe, co w konsekwencji prowadzi do rozpadu napromienianych komórek i lokalnej martwicy tkanek i tak samo dotyczy komórek nowotworowych, jak i zdrowych. Użycie promieni jonizujących wiąże się również z wystąpieniem powikłań popromiennych, tak zwanego odczynu popromiennego. W przypadku raka piersi odczyn może się objawiać w postaci martwicy naskórka lub skóry właściwej, stanu zapalnego wokół zmienionych tkanek, co objawia się wzrostem ciepłoty danego obszaru skóry, obrzmieniem bądź sączeniem się płynu surowiczego [25]. Jednym $z$ efektów leczenia chirurgicznego oraz napromieniania jest wzbudzenie systemów odpowiedzialnych za proces gojenia tkanek, w tym tworzenia stabilnej blizny. Na proces ten wpływają:

- czynniki związane ze stanem zdrowia - stan odżywienia, stopień nawodnienia, dopływ tlenu do tkanek, obecność zakażeń, schorzenia wspólistniejące (cukrzyca, otyłość);

- czynniki związane ze stylem życia - poziom higieny, palenie tytoniu, nadużywanie alkoholu;

- czynniki związane z leczeniem - stosowanie niesteroidowych leków przeciwzapalnych, steroidów, chemioterapeutyków oraz leków immunosupresyjnych [26, 27].

W celu odbudowy tkanek niezbędna jest odpowiednia podaż białka, wzbogacona o wybrane aminokwasy [28-30]. Szczególnie istotne w okresie gojenia są między innymi cysteina i metionina, które związane są z procesem syntezy tkanki lącznej i kolagenu [31]. Arginina wywiera pozytywny wpływ na układ immunologiczny, a jej utlenianie dostarcza tlenku azotu (NO, nitric oxide), który wykazuje działanie antyseptyczne oraz rozszerzające drobne naczynia włosowate, sprzyjając dobremu ukrwieniu rany i dzięki temu zwiększeniu dostępu do substancji odżywczych i tlenu [32]. Natomiast prawidłowe stężenie glutaminy w organizmie sprzyja właściwej produkcji ornityny i argininy jest ona prekursorem syntezy nukleotydów, kwasów nukleinowych, aminocukrów czy glutationu. Ponadto glutamina jest preferowanym źródłem 
energii dla szybko dzielących się komórek, takich jak enterocyty czy komórki układu odpornościowego [27]. Do prawidłowego przebiegu syntezy kolagenu niezbędne są także odpowiednio wysokie stężenia cynku oraz witaminy C. Witamina C uczestniczy w hydroksylacji proliny, lizyny i syntezie kolagenu, gdzie bierze udział w tworzeniu wiązań krzyżowych i stabilizacji potrójnej helisy. Uczestniczy także $\mathrm{w}$ procesie odpowiedzi immunologicznej na uszkodzenie tkanek, wpływa na proces mitozy i migracji monocytów do miejsca zranienia, a także transformacji w makrofagi w fazie zapalnej gojenia [33]. Cynk stanowi kofaktor wielu reakcji enzymatycznych, związanych między innymi $z$ biosyntezą RNA, DNA i białek. Niedobór obu tych składników - witaminy $\mathrm{C}$ i cynku - będzie opóźniał proces gojenia uszkodzonych tkanek, tym samym zwiększając ryzyko jej zakażenia oraz obniżając jakość wytworzonej blizny [26]. Zapobieganie i zwalczanie infekcji jest tymczasem uwarunkowane aktywnością systemu antyoksydacyjnego organizmu, zależnego częściowo od prawidłowej podaży substancji egzogennych - witaminy A, witaminy E, cynku oraz selenu [34]. Dostarczenie tych składników, jak również utrzymanie prawidłowego stanu odżywienia ilościowego i jakościowego będzie wpływało na skrócenie czasu ogólnoustrojowego stanu zapalnego, a tym samym przyspieszenie gojenia tkanek [27]. Stan niedożywienia może sprzyjać także opóźnieniu neowaskularyzacji, obniżeniu wydajności fagocytozy leukocytów czy dysfunkcji leukocytów B i T. Upośledzenie gojenia sprzyja powstawaniu ran przewlekłych, które stanowią ryzyko dla powikłań septycznych ogólnoustrojowych, opóźniając również wprowadzenie kolejnych faz leczenia, zapoczątkowanie procesu rekonwalescencji oraz negatywnie wpływając na jakość życia [35].

$\mathrm{W}$ procesie rekonwalescencji istotną rolę odgrywa stan energetyczny ustroju, a prawidłowa podaż energii mieści się zazwyczaj w przedziale 30-35 kcal/kg mc./dobę. Jej źródłem powinny być głównie węglowodany złożone oraz tłuszcze. Obecność dużej ilości cukrów w diecie nie jest korzystne $z$ powodu zwiększonego ryzyka zakażenia grzybiczego ran [26], natomiast spośród tłuszczów najkorzystniejsze działanie wykazują oleje pochodzenia roślinnego, które są źródłem jedno- i wielonienasyconych kwasów tłuszczowych (PUFA, polyunsaturated fatty-acids), natomiast produkty zawierające kwasy tłuszczowe typu trans nasilają stan zapalany [36]. Podaż i spożycie białka powinny być dostosowane do wyników parametrów oceny stanu odżywienia i wydolności metabolicznej. Pod względem składu najlepszym białkiem jest białko jaja kurzego, ze względu na zbliżony do białka modelowego aminogram. Jednak dostępne powszechnie na rynku preparaty zawierają najczęściej białko pochodzenia mlecznego, którego frakcja kazeinowa może powodować zwiększone wydzielanie kwasu solnego, natomiast frakcja serwatkowa posiada ograniczoną ilość aminokwasów egzogennych.

Śluzówka przewodu pokarmowego $z$ powodu szybkiego tempa wymiany jej komórek jest wrażliwa na działanie leków cytostatycznych. Konsekwencjami podawania chemioterapii mogą być: zmniejszenie apetytu, zmiany smaku, suchość w jamie ustnej, nudności, nietolerancje pokarmowe, zaburzenia jelitowe objawiające się wzdęciami, wymiotami lub biegunkami, a także zapalenie śluzówki jamy ustnej oraz przewodu pokarmowego. Wczesne powikłania występują do 6 tygodni po leczeniu, natomiast w okresie 6-12 miesięcy mogą wystąpić powikłania późne, spośród których wymienia się zwłóknienie miąższu płuc, uszkodzenie nerek, układu nerwowego oraz kardiomiopatie. Mimo że wczesne powikłania są przejściowe, odgrywają one znaczącą rolę w procesie absorpcji składników pokarmowych, które są niezbędne w opisywanych wyżej procesach. Jednym $z$ trudniejszych problemów opieki nad pacjentem poddanym chemioterapii jest leczenie i profilaktyka przeciwzapalna, niezbędne w sytuacji wystąpienia zakażenia [37]. Składnikami pokarmowymi, które wykazują efekt przeciwzapalny są witaminy A, E i C, składniki mineralne: selen, cynk, miedź (są kofaktorami enzymów antyoksydacyjnych) oraz organiczne związki chemiczne $z$ grupy polifenoli (np. antocyjany, flawonoidy, kwercetyna), karotenoidy czy likopen [38]. Ponadto niektóre związki z grupy polifenoli (np. kwas chlorogenowy, resweratrol) wykazują także działanie przeciwnowotworowe na drodze ograniczania stanu zapalnego czy stymulacji apoptozy zmienionych nowotworowo komórek [39]. Do składników pokarmowych, których spożycie będzie miało korzystny wpływ na ograniczenie działań niepożądanych cytostatyków, należą między innymi PUFA omega 3 i glutamina. Włączenie do diety kwasów dokozaheksaenowego (DHA, docosahexaenoic acid) i eikozapentaenowego (EPA, eicosapentaenoic acid) $\mathrm{w}$ trakcie prowadzenia chemio-, ale także radioterapii sprzyja utrzymaniu prawidłowej masy ciała, obniżeniu stanu zapalnego, obniżeniu stresu oksydacyjnego oraz poprawie jakości życia [40]. Dostarczenie glutaminy, której straty wraz $z$ moczem obserwowane są wraz $z$ trwaniem leczenia, potencjalnie ma wplyw natomiast na redukcję symptomów zmęczenia [41] oraz uszczelnienie bariery jelitowej [42]. 
Mimo że powikłania leczenia przeciwnowotworowego są przejściowe, odgrywają one znaczącą rolę $\mathrm{w}$ procesie absorpcji składników pokarmowych, które są niezbędne w opisywanych procesach oraz decydują o utrzymaniu prawidłowego stanu odżywienia. $Z$ tego powodu interwencja żywieniowa powinna być prowadzona wszystkimi dostępnymi metodami, zaczynając od zbilansowania diety metodami naturalnymi, poprzez podawanie doustnych preparatów specjalnego przeznaczenia żywieniowego, kończąc na żywieniu dojelitowym i pozajelitowym. $Z$ uwagi na możliwości uszkodzenia śluzówki i obniżenie wydolności immunologicznej, należy stosować dietę dopasowaną do tolerancji pacjenta, która przybiera najczęściej formę diety lekkostrawnej, ubogo bakteryjnej. Stosowane $\mathrm{w}$ niej techniki kulinarne wiążą się z użyciem wysokiej temperatury i gotowaniem w dużej ilości wody, co prowadzi do strat witamin i składników mineralnych [43]. Ponadto taki rodzaj diety jest ubogi w błonnik pokarmowy, co zmniejsza szansę na utrzymanie prawidłowej flory jelitowej. Konsekwencją długo prowadzonej diety lekkostrawnej ubogo bakteryjnej $z$ dużym prawdopodobieństwem może więc być rozwój niedoborów żywieniowych, które uzupełnione mogą zostać poprzez rozważnie prowadzoną suplementację.

\section{Stan odżywienia i dieta}

Obecność choroby nowotworowej, poprzez modyfikację procesów metabolicznych, wzbudzenie procesów detoksykacji i antyoksydacji, powoduje zmianę zapotrzebowania na podstawowe składniki pokarmowe. Co więcej, zaburzenia funkcjonowania układu pokarmowego oraz zmiany apetytu, będące konsekwencją zarówno leczenia przeciwnowotworowego, jak i powyższych procesów, sprzyjają obniżeniu spożycia produktów spożywczych, w efekcie zwiększając ryzyko niedożywienia. W przypadku kobiet $z$ nowotworem piersi stan odżywienia, określany na podstawie BMI oraz kwestionariusza PG-SGA w większości przypadków wskazuje na prawidłowe odżywienie [44]. W badaniu Mohammadi i wsp. [45] w konsekwencji prowadzonej terapii (mastektomia, chemio-i radioterapia) u 68\% kobiet masa ciała zwiększyła się, a u 32\% - zmniejszyła. Po zakończeniu leczenia $70 \%$ kobiet miało nadwage (wzrost o 16 pkt. proc.), 16\% - otyłość (wzrost o 3 pkt. proc.), a prawidłową masę ciała — jedynie 14\% (spadek o 19 pkt. proc.). Wyniki tego badania przedstawiały ponadto średnie spożycie energii, białka, witamin i składników mineralnych, określone na podstawie metody 3 -dniowego notowania spożycia. Kobiety $z$ badanej grupy w okresie remisji choroby spożywały średnio $1630 \pm 241 \mathrm{kcal} /$ dobę, średnia podaż białka wynosiła 1,09 $\pm 0,2 \mathrm{~g} / \mathrm{kg} \mathrm{mc}$., natomiast odniesione do referencyjnej (rekomendowanej) wartości spożycia (DRI, dietary referance intake) spożycie witaminy D, witaminy E, żelaza i magnezu było niewystarczające. Podobne wyniki zaobserwowano w badaniu Ravasco i wsp. [46], gdzie w grupie kobiet ze średnio 6-miesięczną diagnozą nowotworu piersi po leczeniu radioterapeutycznym stwierdzono zwiększenie masy ciała w $65 \%$ przypadków, natomiast zmniejszenie w $29 \%$. Średnia wartość BMI wyniosła $30 \pm 6 \mathrm{~kg} /$ $/ \mathrm{m}^{2}$, a ponad $1 / 3$ pacjentek była otyła. $\mathrm{W}$ badaniu tym, na podstawie kwestionariusza częstotliwości spożycia żywności (FFQ, Food Frequency Questionnaire), określono spożycie energii oraz procentowy udział energii, pochodzącej $z$ węglowodanów, tłuszczów i białka w diecie. Wyniki wyniosły odpowiednio $2301 \pm 525 \mathrm{kcal} /$ dobę, $18 \pm 3 \%$, $49 \pm 7 \%$ i $37 \pm 7 \%$, wskazując przez to na wysoki udział tłuszczów w diecie, co potwierdza także wysokie spożycie cholesterolu w ilości średnio 330 $\pm 115 \mathrm{mg}$. Jednocześnie średnie spożycie błonnika pokarmowego $(33 \pm 10 \mathrm{~g})$ i wapnia $(1048 \pm$ $\pm 385 \mathrm{mg}$ ) było prawidłowe. Kolejnym badaniem oceniającym zmiany stanu odżywienia, składu ciała oraz jakość diety, przeprowadzonym w grupie kobiet zakwalifikowanych do pierwszej linii leczenia chemioterapeutycznego było prospektywne badanie Custódio i wsp. [15]. Średnia wartość BMI uczestniczek na początku badania wyniosła $28,4 \mathrm{~kg} /$ $/ \mathrm{m}^{2}$ i zwiększyła się istotnie $\mathrm{w}$ toku leczenia, co wskazuje na pogorszenie ich stanu odżywienia w związku ze stosowaną terapią. Po zakończeniu leczenia prawidłową masę ciała miało ponad $41 \%$ badanych, nadwagę $-29,1 \%$, otyłość $-25,5 \%$, a 3,6\% - niedowagę. Zmiana masy ciała dotyczyła głównie osób z niedowagą, którzy po zakończeniu leczenia osiągnęli prawidłową masę ciała. Odsetek kobiet $z$ nadwagą i otyłością nie zmienił się, a wysoka wartość BMI oraz wskaźnika talia-biodra (WHR, waist-to-hip ratio) była skorelowana $z$ niską jakością diety. Ocenę jakości spożywanych posiłków przeprowadzono z użyciem wskaźnika BHEI-R (Brazilian Healthy Eating Index-Revised), który bierze pod uwagę wielkość spożycia poszczególnych grup produktów spożywczych. Ponad połowa kobiet biorąca udział w tym badaniu w okresie przed chemioterapią $\mathrm{i}$ w jej trakcie spożywała dietę wymagającą modyfikacji, natomiast po zakończeniu leczenia najczęściej była to „dieta nieprawidłowa”. Spośród grup produktów, których spożycie istotnie zmniejszyło się wraz $z$ trwaniem terapii było 
ogólne spożycie owoców oraz ciemnozielonych i pomarańczowych warzyw oraz roślin strączkowych. W efekcie istotnymi statystycznie zmianami w diecie były: zmniejszenie spożycia żelaza, magnezu, manganu, cynku, witaminy $\mathrm{C}$, białka, węglowodanów i tłuszczu ogółem, natomiast zwiększenie spożycia cholesterolu, witaminy B1 i B6, co mogło wynikać $z$ utrzymania spożycia mięsa i jaj. Średnie spożycie energii po zakończeniu leczenia wyniosło $1282,6 \pm 265,9 \mathrm{kcal} / \mathrm{dobę}$, a wartość ta zmniejszyła się istotnie $\mathrm{w}$ porównaniu $\mathrm{z}$ okresem sprzed leczenia, wskazując na potrzebę interwencji żywieniowej zarówno w trakcie, jak i po ukończeniu terapii w celu zahamowania niekorzystnych zmian stanu odżywienia.

Zgodnie $z$ wynikami powyższych badań stan odżywienia pacjentek $z$ nowotworami piersi zazwyczaj jest poprawny oraz charakteryzują się one nadmierną masą ciała, która zwiększa się wraz $z$ trwaniem leczenia. Niemniej należy pamiętać, że jest to grupa kobiet, które otrzymały pełną terapię cytostatyczną, często łączoną również z radioterapią oraz zostały poddane zabiegowi operacyjnemu, co powoduje nasilenie procesów katabolicznych oraz naprawczych. Udowodnione w przedstawionych badaniach obniżenie jakości diety $\mathrm{w}$ trakcie terapii i po jej zakończeniu, zmniejszone spożycie wielu składników pokarmowych niezbędnych do prawidłowego przebiegu powyższych procesów, jak również wystąpienie późnych działań niepożądanych terapii powoduje, $\dot{z}$ e kobiety w fazie remisji nowotworu piersi mogą charakteryzować się niedożywieniem jakościowym, mimo obserwowanej nadwagi i otyłości [15, 47], zwiększając ponadto ryzyko rozwoju otyłości sarkopenicznej [48]. W niektórych badaniach, mimo nieodnotowania różnic między dietą kobiet $\mathrm{w}$ okresie choroby nowotworowej a dietą kobiet zdrowych, stwierdzono, ze dieta ta w obu przypadkach nie spełniała zaleceń prawidłowego żywienia [49, 50]. Mając na uwadze powyższe wnioski, interwencja żywieniowa, dedykowana kobietom w okresie remisji nowotworów piersi, powinna zatem koncentrować się głównie wokó1 problemu niedoborów niezbędnych składników pokarmowych (witamin, składników mineralnych, białka) oraz stopniowej redukcji tkanki tłuszczowej.

Do tej pory nie opracowano wytycznych żywienia w okresie remisji nowotworów piersi, jednak specjaliści ze Światowego Funduszu Badań nad Rakiem (WCRF, World Cancer Research Fund International) wskazują, że powinny one się opierać na zasadach profilaktyki pierwotnej, która łączy podstawy prawidłowego żywienia $z$ ograniczeniem wpływu swoistych czynników ryzyka, przedstawionych w tabeli 1. Przyczyną takiego stanu jest brak wystarczającej liczby badań, które przedstawiałyby silne dowody na rekomendację konkretnego modelu żywienia, natomiast istnieją takie, które wskazują na pozytywny lub negatywny wpływ pewnych grup produktów spożywczych oraz składników pokarmowych. Największą wagę w kontekście zwiększania szans przeżycia po osiąnnięciu remisji nowotworów piersi przypisuje się obecnie utrzymaniu prawidłowej masy ciała, regularnej aktywności fizycznej, spożyciu żywności bogatej w błonnik pokarmowy i soję oraz niskiemu spożyciu tłuszczu ogółem, ze szczególnym uwzględnieniem tłuszczów nasyconych [51]. Podejrzewa się również wpływ indeksu glikemicznego diety, spożycia warzyw, owoców, białka, mięsa czerwonego i produktów bogatych w foliany [51-53].

Spośród proponowanych mechanizmów łączących wysokie spożycie tłuszczów i ryzyko nowotworzenia wymienia się predyspozycję do akumulacji tkanki tłuszczowej, co sprzyja zwiększeniu konwersji androgenów w estrogeny (nasilenie aktywności aromatazy zależnej od cytochromu P450) oraz syntezy substancji prozapalnych (czynnik martwicy nowotworów $\alpha$, interleukina 6) [53]. Szczególnie niekorzystny efekt będzie obserwowany u osób $z$ tendencją do gromadzenia tkanki tłuszczowej wisceralnej (otyłość brzuszna), $z$ powodu obserwowanego $u$ nich wyższego stosunku aktywności enzymu dehydrogenazy $17 \beta$-hydroksysteroidowej (17 $\beta$-HSD) do aromatazy, skutkującego wyższym stężeniem we krwi form hormonów steroidowych o wysokiej aktywności - testosteronu i estradiolu. Takie umiejscowienie tkanki tłuszczowej sprzyja również aktywacji kortyzonu do kortyzolu, co prowadzi do lokalnego wzrostu aktywności glikokortykosteroidów i rozwoju insulinooporności [54]. Pozytywną korelację między ryzykiem rozwoju nowotworu piersi a ogólnym spożyciem tłuszczu, bez rozróżnienia na poszczególne jego frakcje, udowodniono w badaniu European Prospective Investigation into Cancer and Nutrition-Potsdam (EPIC-Potsdam), w ramach którego przeprowadzono prospektywną 6-letnią analizę diet $\mathrm{w}$ grupie zdrowych kobiet $\mathrm{w}$ wieku 35-65 lat [55]. $Z$ kolei w badaniu Prentice i wsp. [56] obniżenie spożycia tłuszczu w wyniku interwencji dietetycznej w grupie zdrowych kobiet, połączone ze zwiększeniem spożycia warzyw, owoców i produktów pełnoziarnistych $\mathrm{w}$ porównaniu $\mathrm{z}$ dietą zwykłą spowodowało redukcję zapadalności na ten rodzaj nowotworu o $9 \%$. W przedstawionych badaniach rodzaj spożywanego tłuszczu nie miał wpływu na wyniki obserwacji, jednak sugeruje się, że niekorzystny efekt na rozwój nowotworów 
piersi wykazują kwasy tłuszczowe nasycone, natomiast pozytywny - PUFA omega 3 , tj. EPA i DHA. Mimo braku potwierdzenia tych zależności w badaniach kohortowych, wydaje się, że zalecenie obniżenia spożycia tłuszczów oraz zamiana tłuszczów zwierzęcych na roślinne oraz suplementacja PUFA są rozsądnym kierunkiem w postępowaniu dietetycznym u chorych na nowotwory piersi. Wysokie spożycie kwasów tłuszczowych omega-3 ma pozytywny wplyw nie tylko w prewencji nowotworów (np. poprzez hamowanie peroksydacji lipidów) [57], ale również $\mathrm{w}$ trakcie terapii. $\mathrm{W}$ badaniach Mansara i wsp. [58] suplementacja diety w EPA i DHA w stosunku 1,5:1 powodowała poprawę wskaźników statusu antyoksydacyjnego osocza kobiet $\mathrm{z}$ nowotworami piersi $\mathrm{w}$ trakcie chemioterapii. Co więcej, nawet niewielka poprawa tego stosunku, oceniona na modelach in vitro, wspierała strukturę błony komórkowej komórek oraz spowalniała proliferację komórek nowotworowych [57]. Jedną z przyczyn takiego efektu upatruje się w odmiennym metabolizmie PUFA w komórkach zdrowych i nowotworowych, gdzie w pierwszym przypadku produktami reakcji są lipidy cytoprotekcyjne (resolwiny, protektyny, lipoksyny) [59], $\mathrm{w}$ drugim natomiast toksyczne nadtlenki kwasów tłuszczowych [57]. Ponadto obecność kwasów tłuszczowych omega 3 może potencjalnie modyfikować procesy związane $z$ tworzeniem struktury i adhezją komórek nowotworowych poprzez regulację ekspresji proteoglikanów [60] oraz białek wiążących specyficzne sekwencje DNA (MARBP, matrix attachment region binding proteins) [57].

Wysokie spożycie tłuszczów może wynikać $z$ nadmiaru produktów wysokobiałkowych $\mathrm{w}$ diecie (mięsa, ryb), co wiąże się nierozłącznie ze spożyciem cholesterolu. Związek ten, jako prekursor hormonów steroidowych ma bezpośredni wpływ na wielkość ich endogennej syntezy [61]. Co więcej, spożycie mięsa, szczególnie czerwonego, samo w sobie ma negatywny wpływ na ryzyko rozwoju nowotworów, w tym nowotworów piersi. Za przyczynę tego stanu uważa się powstawanie znacznej ilości związków mutagennych i kancerogennych (heterocyklicznych amin [HA, heterocyclic amines], policyklicznych węglowodorów aromatycznych [PAH, polycyclic aromatic hydrocarbons], nitrozoamin), podczas obróbki termicznej mięsa. Zawartość tych związków w produkcie zwiększa się ze wzrostem temperatury obróbki i jest najwyższa po zastosowaniu metod grillowania tradycyjnego i smażenia [62, 63]. W części badań sugeruje się ponadto związek występowania polimorfizmów genetycznych takich genów, jak: NAT1, NAT2,
GSTM1, GSTT1 i SULT1A1, które kodują enzymy powodujące aktywację lub detoksykację HA $\mathrm{z}$ ryzykiem wystąpienia nowotworu piersi [53].

W odróżnieniu od tłuszczów w przypadku węglowodanów najistotniejsza nie jest wielkość spożycia, a ich rodzaj [53]. Jako węglowodany o korzystnym działaniu wymienia się węglowodany złożone, które pełnią funkcję źródła energii oraz błonnik pokarmowy, łączony najczęściej z modyfikacją pasażu jelitowego oraz mikroflory jelitowej [52]. Negatywny efekt wykazują natomiast węglowodany o krótkim łańcuchu, tak zwane cukry, do których zalicza się glukozę, fruktozę i sacharozę. Jedną $z$ konsekwencji diety obfitującej w cukry jest stale podwyższone stężenie insuliny we krwi, co sprzyja rozwojowi insulinooporności oraz indukcji syntezy IGF-1 w wątrobie [64]. Efektem hiperinsulinemii jest także ograniczenie stężenia białek wiążących IGFBP oraz białek wiążących steroidy płciowe (SHBG, sex hormone-binding globulin), co przyczynia się do zwiększenia biodostępności IGF-1 i estradiolu [65, 66]. Uwrażliwienie na insulinę może poprawić metaboliczny efekt działania insuliny i hamować jej działanie mitogenne. Do metod zwiększających insulinowrażliwość należy stosowanie leków $z$ rodzaju biguanidów (metformina) czy tiazolidynodionu (troglitazon, pioglitazon) [67], spożywanie diety bogatej w błonnik pokarmowy czy aktywność fizyczna [68, 69]. Pozytywny efekt spożywania błonnika pokarmowego może być tłumaczony wpływem na aktywność bakterii mikroflory jelitowej (szczególną rolę odgrywa tu spożywanie prebiotyków), jak również obniżeniem wchłaniania tłuszczów, w tym cholesterolu oraz wchłaniania zwrotnego metabolitów estrogenu [53]. W porównaniu $\mathrm{z}$ niskim spożyciem błonnika pokarmowego jego wysokie spożycie u kobiet w remisji nowotworów piersi wydaje się redukować ryzyko śmiertelności ogólnej [51]. W odniesieniu do ogólnego spożycia cukrów oraz wartości indeksu glikemicznego diety obecnie brakuje wystarczająco silnych dowodów, by potwierdzić ich negatywny wpływ na ryzyko rozwoju nowotworów piersi, jednak jest on udowodniony $\mathrm{w}$ odniesieniu do niektórych czynników ryzyka - hiperinsulinemii czy obecności zaburzeń metabolicznych [52, 70].

W kontekście spożycia białka w okresie regeneracji istotna jest uprzednia ocena jego niedoborów i indywidualne dostosowanie wielkości spożycia. W początkowym okresie może wymagać ono zastosowania doustnych suplementów pokarmowych, jeśli na przykład wyniki stężenia albumin/ /prealbumin są obniżone, a możliwość uzupełnienia niedoborów za pomocą produktów tradycyjnych 
jest utrudniona $z$ powodu późnych powikłań terapii. Źródło białka w diecie może być zarówno pochodzenia zwierzęcego, jak i roślinnego, przy czym spożywanie wyłącznie białka pochodzenia roślinnego, bez należytego ich zróżnicowania, może wiązać się $z$ ryzykiem niedoborów aminokwasów egzogennych [71]. Natomiast obecność w diecie wysokobiałkowych produktów roślinnych jakimi są nasiona roślin strączkowych wiąże się $\mathrm{z}$ dodatkowymi korzyściami $\mathrm{w}$ postaci większego spożycia błonnika pokarmowego i roślinnych związków bioaktywnych [72]. W związku $z$ istotną rolą IGF-1 w procesie nowotworzenia niezalecanym źródłem białka w diecie kobiet $z$ nowotworami piersi oraz zwiększonym ryzykiem ich wystąpienia wydają się produkty mleczne [73]. Składnikami mleka, które poprzez wpływ na aktywność kinazy serynowo-treoninowej mTOR (mammalian target of rapamycin kinase) mogą modyfikować wzrost, namnażanie i apoptozę komórek są aminokwasy rozgałęzione (BCAA, branched-chain amino acids) oraz egzosomalne regulatorowe mikroRNA (miRs - cząsteczki jednoniciowego RNA) [74]. Cząsteczki jednoniciowego RNA, których głównym egzogennym źródłem w diecie człowieka jest mleko wykazują możliwość regulacji ekspresji genów na poziomie translacji. Przykładowo, miR-21 $\mathrm{w}$ wyniku tłumienia genów supresorowych ogranicza możliwość indukcji apoptozy w komórkach nowotworowych, przez co wykazuje działanie onkogenne [75]. Obecność w mleku znacznych ilości tryptofanu, który jest prekursorem serotoniny pośrednio powoduje nasilenie uwalniania $\mathrm{GH}$ i syntezę IGF-1 w wątrobie. Tymczasem zawartość BCAA, szczególnie leucyny, promuje uwalnianie insuliny oraz proliferację komórek $\beta$ trzustki. W zależności od frakcji białka mlecznego efekt na procesy metaboliczne jest odmienny, jednak w obu przypadkach ostatecznie powoduje nasilenie procesów wzrostu [76]. Spożycie białka serwatkowego sprzyja hiperinsulinemii, zwiększonej aktywności komórek $\beta$ oraz $\mathrm{w}$ insulinooporności, natomiast białka kazeinowego — wyższym stężeniom IGF-1 oraz jego zwiększonej biodostępności [77]. Synteza IGF-1 zależy ściśle od dostępności aminokwasów, a prawidłowa lub zwiększona zawartość aminokwasów egzogennych $\mathrm{w}$ diecie po okresie głodzenia jest wymagana do przywrócenia jego prawidłowego wydzielania oraz odbudowy tkanki mięśniowej. Aczkolwiek wydaje się, że nadmiar spożycia białka znacznie przekraczający zapotrzebowanie może w dłuższym okresie zaburzać naturalne mechanizmy regulujące procesy wzrostowe [78]. Mimo możliwości dostarczania aminokwasów również z innymi rodzajami białka, tym co odróżnia od nich białko mleka jest wyższa niż na przykład w białku jajecznym i wołowym zawartość leucyny i lizyny, a w odniesieniu tylko do białka wołowego — także tryptofanu, izoleucyny, fenyloalaniny i tyrozyny [79]. Wpływ zwiększonego spożycia białka $z$ produktów mlecznych na wzrost stężenia IGF-1 i obniżenia IGFBP został udowodniony w badaniu European Prospective Investigation into Cancer and Nutrition (EPIC), przeprowadzonym przez Crowe i wsp. [65] z udziałem osób zdrowych. Takiej zależności nie udowodniono natomiast w odniesieniu do innych źródeł białka. Dodatkowo istotny jest fakt, że zawartość miRs oraz IGF-1 w mleku zmniejsza się tylko nieznacznie w trakcie obróbki cieplnej $[73,80]$, co oznacza występowanie tych związków nie tylko w świeżym mleku, ale także w jego przetworach i potrawach.

Do produktów spożywczych, które powinny być zalecane kobietom $\mathrm{z}$ nowotworami piersi w prewencji pierwotnej i wtórnej są warzywa i owoce. Natomiast szczególnie korzystny wpływ będą miały te o wysokiej zawartości kwasu foliowego, antyoksydantów oraz związków bioaktywnych. Do składników o udowodnionym pozytywnym wpływie na redukcję ryzyka nowotworów piersi zalicza się: karotenoidy [81], flawonoidy, izoflawony czy izotiocyjaniany $[82,83]$. W metaanalizie Eliassen i wsp. [84] obniżenie ryzyka rozwoju nowotworu piersi stwierdzono wśród tych kobiet, które miały we krwi wyższe stężenie karotenoidów ogółem, jak również ich poszczególnych rodzajów: likopenu, $\beta$ - i $\alpha$-karotenu oraz luteiny z zeaksantyną. Wydaje się, że najsilniejszy efekt działania spośród tych związków wykazuje likopen, który poprzez wpływ na system detoksykacyjny i antyoksydacyjny organizmu oraz interakcje $z$ białkami biorącymi udział w procesach cyklu komórkowego oraz przekazywania sygnału wewnątrz komórki może wspierać funkcje organizmu w przebiegu choroby nowotworowej [83]. Izoflawony (daidzeina, genisteina), których źródłem są rośliny strączkowe, a w szczególności soja, ze względu na zbliżoną do estrogenów strukturę chemiczną mają możliwość interakcji $z$ jego receptorami. Efektem jest obniżenie pobudzenia ERs $z$ powodu mniejszej niż estrogeny aktywności hormonalnej izoflawonów. Ponadto związki te wykazują zdolność hamowania kinaz tyrozynowych uczestniczących w procesach proliferacji i angiogenezy. Metaanalizy badań Qin i wsp. [85] oraz Trock i wsp. [86], określające ryzyko rozwoju nowotworu piersi w zależności od spożycia produktów sojowych oraz białka sojowego wskazały na kolejno 25 - i 15-procentową redukcje 
Tabela 2. Modyfikacje żywieniowe wpływające na wzrost ryzyka rozwoju nowotworów piersi (na podstawie [52, 53])

Table 2. Dietary modifications that increase the risk of developing breast cancer (based on $[52,53]$ )

\begin{tabular}{|c|c|c|c|c|c|}
\hline \multicolumn{2}{|l|}{ Modyfikacja żywieniowa } & \multicolumn{2}{|l|}{$\begin{array}{l}\text { Zmiany spożycia składników } \\
\text { pokarmowych }\end{array}$} & \multirow{2}{*}{\begin{tabular}{|l|} 
Efekt metaboliczny \\
$\uparrow$ stanu zapalnego, zaburzeń struktury błony \\
komórkowej \\
$\uparrow$ tkanki tłuszczowowej \\
$\uparrow$ stężenia estrogenów we krwi
\end{tabular}} & \multirow{4}{*}{ 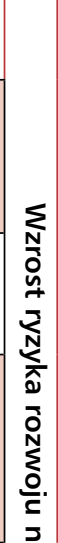 } \\
\hline $\begin{array}{l}\text { 个tłuszczów ogółem } \\
\downarrow \text { PUFA }\end{array}$ & $\rightarrow$ & $\begin{array}{l}\uparrow \text { SFA, cholesterolu } \\
\downarrow \text { DHA + EPA }\end{array}$ & $\rightarrow$ & & \\
\hline $\begin{array}{l}\text { } \text { mięsa (czerwonego, grillo- } \\
\text { wanego, smażonego, wysoko- } \\
\text { przetworzonego) }\end{array}$ & $\rightarrow$ & $\begin{array}{l}\uparrow H A, P A H, \text { nitrozamin } \\
\uparrow S F A \text {, cholesterolu, Fe }\end{array}$ & $\rightarrow$ & $\begin{array}{l}\text { 个działania mutagennego i kancerogennego } \\
\text { } \text { stężenia estrogenów i androgenów }\end{array}$ & \\
\hline $\begin{array}{l}\text { } \text { węglowodanów prostych } \\
\downarrow \text { węglowodanów złożonych }\end{array}$ & $\rightarrow$ & $\begin{array}{l}\uparrow \text { sacharozy, glukozy, fruktozy } \\
\downarrow \text { błonnika pokarmowego }\end{array}$ & $\rightarrow$ & $\begin{array}{l}\text { Thiperinsulinemii, insulinooporności, IGF-1 } \\
\uparrow \text { biodostępności estrogenów i IGF-1 } \\
\uparrow \text { proliferacji } \\
\downarrow \text { apoptozy } \\
\uparrow \text { dysbiozy mikroflory jelitowej } \\
\end{array}$ & \\
\hline 个produktów mlecznych & $\rightarrow$ & $\begin{array}{l}\text { Ttryptofanu, BCAA (leucyna), } \\
\text { miRs }\end{array}$ & $\rightarrow$ & $\begin{array}{l}\text { 个GH, syntezy i biodostępności IGF-1 } \\
\text { } \text { hiperinsulinemii, insuliooporności } \\
\uparrow \text { proliferacji }\end{array}$ & $\sum_{\substack{0 \\
\vdots}}^{\overline{0}}$ \\
\hline $\begin{array}{l}\downarrow \text { warzyw i owoców } \\
\downarrow \text { roślin strączkowych }\end{array}$ & $\rightarrow$ & $\begin{array}{l}\downarrow \text { przeciwutleniaczy } \\
\downarrow \text { kwasu foliowego } \\
\downarrow \text { błonnika pokarmowego } \\
\downarrow \text { związków bioaktywnych } \\
\text { (karotenoidy, flawonoidy, } \\
\text { izoflawony, izotiocyjaniany) }\end{array}$ & $\rightarrow$ & $\begin{array}{l}\text { 个procesu zapalnego } \\
\text { 个uszkodzenia DNA }\end{array}$ & 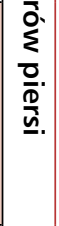 \\
\hline 个alkoholu & $\rightarrow$ & $\uparrow$ etanolu & $\rightarrow$ & $\begin{array}{l}\text { } \text { uszkodzenia DNA, stresu oksydacyjnego } \\
\downarrow \text { wchłaniania kwasu foliowego } \\
\uparrow \text { stężenia estrogenu }\end{array}$ & \\
\hline
\end{tabular}

PUFA (polyunsaturated fatty-acids) - wielonienasycone kwasy tłuszczowe; SFA (saturated fatty acids) - nasycone kwasy tłuszczowe; DHA (docosahexaenoic acid) — kwas dokozaheksaenowy; EPA (eicosapentaenoic acid) - kwas eikozapentaenowy; HA (heterocyclic amines) - heterocykliczne aminy; PAH (polycyclic aromatic hydrocarbons) - policykliczne węglowodory aromatyczne; Fe - żelazo; BCAA (branched-chain amino acids) — aminokwasy rozgałęzione; miRs - regulatorowe mikroRNA; GH (growth hormone) - hormon wzrostu; IGF-1 (insulin-like growth factor-1) - insulinopodobny czynnik wzrostu 1; DNA (deoxyribonucleic acid) - kwas deoksyrybonukleinowy

tego ryzyka w grupie kobiet spożywających największe ich ilości $\mathrm{w}$ porównaniu $\mathrm{z}$ najmniejszym spożyciem. Na podstawie wyników większości badań można stwierdzić, że szczególnie korzystny wpływ wynikający ze spożycia soi wykazują populacje azjatyckie, jednak przyczyną takiego stanu może być ograniczona liczba badań w innych obszarach świata, gdzie notuje się zazwyczaj niskie spożycie roślin strączkowych. $Z$ tego powodu, mimo braku wystarczająco silnych dowodów, sugeruje się obecnie pozytywną korelację między spożyciem produktów sojowych i redukcją ryzyka nowotworów piersi $[82,87]$.

W przypadku kobiet pozostających w remisji raka piersi, szczególnie tych mających nadwage lub otyłość, udowodniono, że zmodyfikowany profil diety w kierunku zdrowego żywienia oraz zwiększenie aktywności fizycznej mają pozytywny wpływ na jakość ich życia, wydolność organizmu, a także potencjalnie na poprawe prognozy przeżycia [88]. Odnosząc do konkretnych zaleceń żywieniowych efekty działania opisanych wyżej składników pokarmowych, które zostały zawarte także $\mathrm{w}$ tabeli 2 , w diecie kobiet $\mathrm{w}$ remisji no- wotworów piersi powinny dominować warzywa i owoce oraz produkty obfitujące $\mathrm{w}$ węglowodany złożone, zawierające błonnik pokarmowy (produkty zbożowe $z$ pełnego ziarna, suche nasiona roślin strączkowych). Uzupełnieniem posiłków powinny być produkty dostarczające tłuszcze roślinne (oleje, orzechy i pestki) oraz białko: chude produkty mleczne (w obniżonej ilości - nie powinny być głównym źródłem białka), jaja, mięso drobiowe, suche nasiona roślin strączkowych, jak również ryby, których tłuste, głównie morskie odmiany są bogatym źródłem DHA i EPA. Natomiast produktami, które powinny być spożywane sporadycznie lub wykluczone $z$ diety są przetworzone produkty mięsne (głownie wytwarzane $z$ czerwonego mięsa oraz grillowane tradycyjnie oraz smażone), tłuszcze zwierzęce, słodycze i napoje słodzone. Taki sposób żywienia wydaje się dobrym punktem wyjścia do indywidualnie zaprojektowanej interwencji żywieniowej, która powinna uwzględniać również choroby towarzyszące i aktualny stan odżywienia danej pacjentki. Niezbędne jest dalsze prowadzenie badań, zarówno w aspekcie rozpoznawania kolejnych składników pokarmowych o pozytywnym lub 
negatywnym wpływie na ryzyko rozwoju nowotworów piersi oraz na czas przeżycia, jak również $\mathrm{w}$ aspekcie całościowego wpływu diety w grupie kobiet $\mathrm{w}$ remisji choroby.

\section{Piśmiennictwo}

1. Wojciechowska U, Olasek P, Czauderna K, Didkowska J. Nowotwory złośliwe w Polsce w 2014 roku. Centrum Onkologii - Instytut, Warszawa 2016.

2. Ferlay J, Soerjomataram I, Ervik M, et al. GLOBOCAN 2012 v1.0, Cancer Incidence and Mortality Worldwide: IARC CancerBase No. 11 [Internet]. International Agency for Research on Cancer, Lyon 2013. Available from. http://globocan.iarc.fr (2013).

3. O'Brien J, Martinson H, Durand-Rougely C, et al. Macrophages are crucial for epithelial cell death and adipocyte repopulation during mammary gland involution. Development. 2012; 139(2): 269-275, doi: 10.1242/dev.071696, indexed in Pubmed: 22129827.

4. Stein T, Salomonis N, Nuyten DSA, et al. A mouse mammary gland involution mRNA signature identifies biological pathways potentially associated with breast cancer metastasis. J Mammary Gland Biol Neoplasia. 2009; 14(2): 99-116, doi: 10.1007/s10911-009-9120-1, indexed in Pubmed: 19408105.

5. Law AMK, Lim E, Ormandy CJ, et al. The innate and adaptive infiltrating immune systems as targets for breast cancer immunotherapy. Endocr Relat Cancer. 2017; 24(4): R123-R144, doi: 10.1530/ERC-16-0404, indexed in Pubmed: 28193698.

6. Lakhani S, Ellis I, Schnitt S, et al. WHO classification of tumours of the breast. $4^{\text {th }}$ ed. IARC Press, Lyon 2012.

7. Shao M, Hollar S, Chambliss D, et al. Targeting the insulin growth factor and the vascular endothelial growth factor pathways in ovarian cancer. Mol Cancer Ther. 2012; 11(7): 1576-1586, doi: 10.1158/1535-7163.MCT-11-0961, indexed in Pubmed: 22700681.

8. Dębska S, Potemski P. Leczenia hormonalne chorych na raka piersi z nadekspresją receptora HER2. Onkol Prak Klin. 2010; 6: 301-310.

9. Noruzinia M, Coupier I, Pujol P. Is BRCA1/BRCA2-related breast carcinogenesis estrogen dependent? Cancer. 2005; 104(8): 1567-1574, doi: 10.1002/cncr.21367, indexed in Pubmed: 16155942.

10. Christopoulos PF, Msaouel P, Koutsilieris M. The role of the insulin-like growth factor-1 system in breast cancer. Mol Cancer. 2015; 14: 43, doi: 10.1186/s12943-015-0291-7, indexed in Pubmed: 25743390 .

11. Parl FF, Egan KM, Li C, et al. Estrogen exposure, metabolism, and enzyme variants in a model for breast cancer risk prediction. Cancer Inform. 2009; 7: 109-121, indexed in Pubmed: 19718449 .

12. Goździcka-Józefiak A, Bobowicz MA, Kędzia H. Geny a nowotwory. W: Genetyka molekularna i biochemia wybranych chorób u ludzi. UAM, Poznań 2001.

13. Nowaczyk M. Rak piersi u kobiet. Krajowy Rejestr Nowotworów. http://onkologia.org.pl/rak-piersi-kobiet (26.04.2017).

14. Pertyński T, Stachowiak G. Menopauza — fakty i kontrowersje. Pol J Endocrinol. 2006; 57: 525-534.

15. Custódio ID, Marinho Ed, Gontijo CA, et al. Impact of chemotherapy on diet and nutritional status of women with breast cancer: a prospective study. PLoS One. 2016; 11(6): e0157113, doi: 10.1371/journal.pone.0157113, indexed in Pubmed: 27310615.

16. Biela A, Pacholska-Bogacka J. Nowotwory hormonozależne u kobiet. Nowa Med. 2012; 4: 76-81.
17. Gierach GL, Yang XR, Figueroa JD, et al. Emerging concepts in breast cancer risk prediction. Curr Obstet Gynecol Rep. 2013; 2(1): 43-52, doi: 10.1007/s13669-012-0034-3, indexed in Pubmed: 25506515 .

18. Jaśkiewicz J, Pieńkowski T. Rak piersi — rozpoznawanie, leczenie, profilaktyka. Przew Lek. 2000; 6: 47-53.

19. Niemiec J, Ryś J. Podtyp podstawny raka piersi — jednostka o specyficznej charakterystyce immunofenotypowej? Pol J Pathol. 2009; 3(Suppl 1): S36-S44.

20. Krzakowski M, Warzocha K. Zalecenia postępowania diagnostyczno-terapeutycznego w nowotworach złośliwych -2013 rok. Via Medica, Gdańsk 2013: 229.

21. Deptała A, Wojtukiewicz MZ. Onkologia w praktyce lekarza rodzinnego. AsteriaMed, Gdańsk 2016.

22. Beatson GT. On the treatment of inoperable cases of carcinoma of the mamma: suggestions for a new method of treatment, with illustrative cases.1. Lancet. 1896; 148(3802): 104-107, doi: 10.1016/s0140-6736(01)72307-0.

23. Krzakowski M. Podstawy kliniczne hormonoterapii nowotworów. In: Krzakowski M. ed. Onkologia kliniczna. Borgis, Warszawa 2001: 65-82.

24. Winczura P, Senkus-Konefka E, Jassem J. Polskie i międzynarodowe zalecenia dotyczące leczenia raka piersi. Nowotwory J Oncol. 2013; 63: 58-65.

25. Gajewski P, Szczeklik A. Interna Szczeklika. Podręcznik chorób wewnętrznych. Medycyna Praktyczna, Kraków 2016: 2253.

26. MacKay D, Miller AL. Nutritional support for wound healing. Altern Med Rev. 2003; 8(4): 359-377, indexed in Pubmed: 14653765.

27. Anderson K, Hamm RL. Factors that impair wound healing. J Am Coll Clin Wound Spec. 2012; 4(4): 84-91, doi: 10.1016/j. jccw.2014.03.001, indexed in Pubmed: 26199879.

28. Schlemmer M, Suchner U, Schäpers B, et al. Is glutamine deficiency the link between inflammation, malnutrition, and fatigue in cancer patients? Clin Nutr. 2015; 34(6): 1258-1265, doi: 10.1016/j. clnu.2014.12.021, indexed in Pubmed: 25614125.

29. Cao Yu, Feng Y, Zhang Y, et al. L-Arginine supplementation inhibits the growth of breast cancer by enhancing innate and adaptive immune responses mediated by suppression of MDSCs in vivo. BMC Cancer. 2016; 16: 343, doi: 10.1186/s12885-016-2376-0, indexed in Pubmed: 27246354.

30. Engelen MP, Klimberg VS, Allasia A, et al. PP288-SUN: surgery reduces de novo arginine production independent of the presence of breast cancer. Clin Nutr. 2014; 33: S127, doi: 10.1016/s0261$-5614(14) 50329-9$.

31. Posthauer ME, Posthauer ME. The role of nutrition in wound care. Adv Skin Wound Care. 2006; 19(1): 43-52; quiz 53, doi: 10.1097/00129334-200601000-00015, indexed in Pubmed: 16477165.

32. Witte MB, Barbul A. Arginine physiology and its implication for wound healing. Wound Repair Regen. 2003; 11(6): 419-423, doi: 10.1046/j.1524-475x.2003.11605.x, indexed in Pubmed: 14617280.

33. Ross V. Micronutrient recommendations form wound healing. Support Line. 2002; 24: 3-9.

34. Rahman K. Studies on free radicals, antioxidants, and co-factors. Clin Interv Aging. 2007; 2(2): 219-236.

35. Guo S, Dipietro LA. Factors affecting wound healing. J Dent Res. 2010; 89(3): 219-229, doi: 10.1177/0022034509359125, indexed in Pubmed: 20139336.

36. Fritsche KL. The science of fatty acids and inflammation. Adv Nutr. 2015; 6(3): 293S-301S, doi: 10.3945/an.114.006940, indexed in Pubmed: 25979502. 
37. Zaborowska A. Opieka nad pacjentem poddawanym chemioterapii. In: Dębska G, Pasek M. ed. Interdyscyplinarna opieka nad pacjentem $z$ chorobą nowotworową. Oficyna Wydawnicza AFM, Kraków 2011.

38. Szajdek A, Borowska J. Właściwości przeciwutleniające żywności pochodzenia roślinnego. ŻNTJ. 2004; 4: 5-28.

39. Paszkiewicz M, Budzyńska A, Różalska B. Immunomodulacyjna rola polifenoli roślinnych. Postepy Hig Med Dosw. 2012; 66: 637-646.

40. de Aguiar Pastore Silva J, Emilia de Souza Fabre M, Waitzberg DL. Omega-3 supplements for patients in chemotherapy and/ /or radiotherapy: a systematic review. Clin Nutr. 2015; 34(3): 359-366, doi: 10.1016/j.clnu.2014.11.005, indexed in Pubmed: 25907586 .

41. Hugh Dunstan R, Sparkes DL, Macdonald MM, et al. Altered amino acid homeostasis and the development of fatigue by breast cancer radiotherapy patients: a pilot study. Clin Biochem. 2011; 44(2-3): 208-215, doi: 10.1016/j.clinbiochem.2010.10.002, indexed in Pubmed: 20950596

42. Beutheu S, Ouelaa W, Guérin C, et al. Glutamine supplementation, but not combined glutamine and arginine supplementation, improves gut barrier function during chemotherapy-induced intestinal mucositis in rats. Clin Nutr. 2014; 33(4): 694-701, doi: 10.1016/j.clnu.2013.09.003, indexed in Pubmed: 24095638.

43. Różańska D, Regulska-Ilow B, Ilow R. Wpływ wybranych procesów kulinarnych na potencjał antyoksydacyjny i zawartość polifenoli w żywności. Probl Hig Epidemiol. 2014; 95: 215-222.

44. Ramos Chaves M, Boléo-Tomé C, Monteiro-Grillo I, et al. The diversity of nutritional status in cancer: new insights. Oncologist. 2010; 15(5): 523-530, doi: 10.1634/theoncologist.2009-0283, indexed in Pubmed: 20395552.

45. Mohammadi S, Sulaiman S, Koon PB, et al. Association of nutritional status with quality of life in breast cancer survivors. Asian Pac J Cancer Prev. 2013; 14(12): 7749-7755, doi: 10.7314/ /apjcp.2013.14.12.7749, indexed in Pubmed: 24460363.

46. Ravasco P, João DR. MON-LB010: what is the pattern of diet, nutritional status and body fat in women with breast cancer? Clin Nutr. 2015; 34: S254, doi: 10.1016/s0261-5614(15)30774-3.

47. Zhang FF, Liu S, John EM, et al. Diet quality of cancer survivors and noncancer individuals: results from a national survey. Cancer. 2015; 121(23): 4212-4221, doi: 10.1002/cncr.29488, indexed in Pubmed: 26624564.

48. Prado CMM, Baracos VE, McCargar LJ, et al. Sarcopenia as a determinant of chemotherapy toxicity and time to tumor progression in metastatic breast cancer patients receiving capecitabine treatment. Clin Cancer Res. 2009; 15(8): 2920-2926, doi: 10.1158/1078-0432.CCR-08-2242, indexed in Pubmed: 19351764.

49. Milliron BJ, Vitolins MZ, Tooze JA. Usual dietary intake among female breast cancer survivors is not significantly different from women with no cancer history: results of the National Health and Nutrition Examination Survey, 2003-2006. J Acad Nutr Diet. 2014; 114(6): 932-937, doi: 10.1016/j.jand.2013.08.015, indexed in Pubmed: 24169415.

50. Zuniga KE, Mackenzie MJ, Roberts SA, et al. Relationship between fruit and vegetable intake and interference control in breast cancer survivors. Eur J Nutr. 2015; 55(4): 1555-1562, doi: 10.1007/s00394-015-0973-3, indexed in Pubmed: 26123915.

51. World Cancer Research Fund International/American Institute for Cancer Research Continuous Update Project Report: diet, nutrition, physical activity, and breast cancer survivors 2014.

52. Mourouti N, Kontogianni MD, Papavagelis C, et al. Diet and breast cancer: a systematic review. Int J Food Sci Nutr. 2015; 66(1): 1-42, doi: 10.3109/09637486.2014.950207, indexed in Pubmed: 25198160.
53. Kotepui M. Diet and risk of breast cancer. Contemp Oncol (Pozn). 2016; 20(1): 13-19, doi: 10.5114/wo.2014.40560, indexed in Pubmed: 27095934.

54. Skowrońska B, Fichna M, Fichna P. Rola tkanki tłuszczowej w układzie endokrynnym. Endokrynologia. 2005; 1: 21-29.

55. Schulz M, Hoffmann K, Weikert C, et al. Identification of a dietary pattern characterized by high-fat food choices associated with increased risk of breast cancer: the European Prospective Investigation into Cancer and Nutrition (EPIC)-Potsdam Study. Br J Nutr. 2008; 100(5): 942-946, doi: 10.1017/S0007114508966149, indexed in Pubmed: 18377685.

56. Prentice RL, Caan B, Chlebowski RT, et al. Low-fat dietary pattern and risk of invasive breast cancer: the Women's Health Initiative Randomized Controlled Dietary Modification Trial. JAMA. 2006; 295(6): 629-642, doi: 10.1001/jama.295.6.629, indexed in Pubmed: 16467232 .

57. Mansara PP, Deshpande RA, Vaidya MM, et al. Differential ratios of omega fatty acids (AA/EPA+DHA) modulate growth, lipid peroxidation and expression of tumor regulatory MARBPs in breast cancer cell lines MCF7 and MDA-MB-231. PLoS One. 2015; 10(9): e0136542, doi: 10.1371/journal.pone.0136542, indexed in Pubmed: 26325577.

58. Mansara P, Ketkar M, Deshpande R, et al. Improved antioxidant status by omega-3 fatty acid supplementation in breast cancer patients undergoing chemotherapy: a case series. J Med Case Rep. 2015; 9: 148, doi: 10.1186/s13256-015-0619-3, indexed in Pubmed: 26104023.

59. Filipczyk LM, Wystrychowski A. Wygaszanie reakcji zapalnej przez pochodne $\omega-3$ i $\omega-6$ wielonienasyconych kwasów tłuszczowych. Nefrol Dial Pol. 2011; 15: 43-52.

60. Sun H, Berquin IM, Edwards IJ. Omega-3 polyunsaturated fatty acids regulate syndecan-1 expression in human breast cancer cells. Cancer Res. 2005; 65(10): 4442-4447, doi: 10.1158/0008-5472.CAN-04-4200, indexed in Pubmed: 15899837.

61. Boyd NF, Stone J, Vogt KN, et al. Dietary fat and breast cancer risk revisited: a meta-analysis of the published literature. $\mathrm{Br}$ J Cancer. 2003; 89(9): 1672-1685, doi: 10.1038/sj.bjc.6601314, indexed in Pubmed: 14583769.

62. Knize MG, Felton JS. Formation and human risk of carcinogenic heterocyclic amines formed from natural precursors in meat. Nutr Rev. 2005; 63(5): 158-165, doi: 10.1301/nr.2005.may.158-165, indexed in Pubmed: 15971410.

63. Majcherczyk J, Surówka K. Heterocykliczne aminy aromatyczne jako zagrożenie w produktach mięsnych poddawanych obróbce termicznej. ŻNTJ. 2015; 1: 16-34.

64. Barnard RJ. Prostate cancer prevention by nutritional means to alleviate metabolic syndrome. Am J Clin Nutr. 2007; 86(3): s889-s893, indexed in Pubmed: 18265484.

65. Crowe FL, Key TJ, Allen NE, et al. The association between diet and serum concentrations of IGF-I, IGFBP-1, IGFBP-2, and IGFBP-3 in the European Prospective Investigation into Cancer and Nutrition. Cancer Epidemiol Biomarkers Prev. 2009; 18(5): 1333-1340, doi: 10.1158/1055-9965.EPI-08-0781, indexed in Pubmed: 19423514.

66. Gupta K, Krishnaswamy G, Karnad A, et al. Insulin: a novel factor in carcinogenesis. Am J Med Sci. 2002; 323(3): 140-145, indexed in Pubmed: 11908858.

67. Kacalska O, Krzyczkowsk-Sendrakowska M, Milewicz T. Molekularne podstawy antynowotworowego działania uwrażliwiaczy na insulinę. Endokrynol Pol. 2005; 3: 308-313.

68. Hinderliter AL, Babyak MA, Sherwood A, et al. The DASH diet and insulin sensitivity. Curr Hypertens Rep. 2011; 13(1): 67-73, doi: 10.1007/s11906-010-0168-5, indexed in Pubmed: 21058045. 
69. Bindels LB, Walter J, Ramer-Tait AE. Resistant starches for the management of metabolic diseases. Curr Opin Clin Nutr Metab Care. 2015; 18(6): 559-565, doi: 10.1097/ /MCO.0000000000000223, indexed in Pubmed: 26406392.

70. Romieu I, Ferrari P, Rinaldi S, et al. Dietary glycemic index and glycemic load and breast cancer risk in the European Prospective Investigation into Cancer and Nutrition (EPIC). Am J Clin Nutr. 2012; 96(2): 345-355, doi: 10.3945/ajcn.111.026724, indexed in Pubmed: 22760570.

71. Craig W. Nutrition concerns and health effects of vegetarian diets. Nutr Clin Pract. 2010; 25(6): 613-620, doi: 10.1177/0884533610385707, indexed in Pubmed: 21139125.

72. Marsh KA, Munn EA, Baines SK. Protein and vegetarian diets. Med J Aust. 2013; 199(4 Suppl): S7-SS10, indexed in Pubmed: 25369930.

73. Melnik BC, John SM, Schmitz G. Milk is not just food but most likely a genetic transfection system activating mTORC1 signaling for postnatal growth. Nutr J. 2013; 12: 103, doi: 10.1186/1475-2891-12-103, indexed in Pubmed: 23883112.

74. Regulska K, Stanisz B, Regulski M. Indywidualizacja terapii przeciwnowotworowej; molekularne uwarunkowania mechanizmów działania nowoczesnych leków onkologicznych. Postepy Hig Med Dosw. (online. 2012; 66: 855-867, doi: 10.5604/17322693.1019649.

75. Buscaglia LE, Li Y. Apoptosis and the target genes of microRNA-21. Chin J Cancer. 2011; 30(6): 371-380, indexed in Pubmed: 21627859.

76. Yang J, Chi Y, Burkhardt BR, et al. Leucine metabolism in regulation of insulin secretion from pancreatic beta cells. Nutr Rev. 2010; 68(5): 270-279, doi: 10.1111/j.1753-4887.2010.00282.x, indexed in Pubmed: 20500788.

77. Hoppe C, Mølgaard C, Dalum C, et al. Differential effects of casein versus whey on fasting plasma levels of insulin, IGF-1 and IGF-1/ /IGFBP-3: results from a randomized 7-day supplementation study in prepubertal boys. Eur J Clin Nutr. 2009; 63(9): 1076-1083, doi: 10.1038/ejcn.2009.34, indexed in Pubmed: 19471293.

78. Melnik BC, John SM, Schmitz G. Over-stimulation of insulin/IGF-1 signaling by western diet may promote diseases of civilization: lessons learnt from laron syndrome. Nutr Metab (Lond). 2011; 8: 41, doi: 10.1186/1743-7075-8-41, indexed in Pubmed: 21699736.

79. Kunachowicz H. Tabele składu i wartości odżywczej żywności. Wydawnictwo Lekarskie PZWL, Warszawa 2005.

80. Goelz R, Hihn E, Hamprecht K, et al. Effects of different CMV-heat-inactivation-methods on growth factors in human breast milk. Pediatr Res. 2009; 65(4): 458-461, doi: 10.1203/ /PDR.0b013e3181991f18, indexed in Pubmed: 19127217.

81. Bakker MF, Peeters PHm, Klaasen VM, et al. Plasma carotenoids, vitamin $\mathrm{C}$, tocopherols, and retinol and the risk of breast cancer in the European Prospective Investigation into Cancer and Nutrition cohort. Am J Clin Nutr. 2016; 103(2): 454-464, doi: 10.3945/ /ajcn.114.101659, indexed in Pubmed: 26791185.

82. Baena Ruiz R, Salinas Hernández P. Cancer chemoprevention by dietary phytochemicals: epidemiological evidence. Maturitas. 2016; 94: 13-19, indexed in Pubmed: 27823732.

83. Milani A, Basirnejad M, Shahbazi S, et al. Carotenoids: biochemistry, pharmacology and treatment. Br J Pharmacol. 2017; 174(11): 1290-1324, doi: 10.1111/bph.13625, indexed in Pubmed: 27638711.

84. Eliassen AH, Hendrickson SJ, Brinton LA, et al. Circulating carotenoids and risk of breast cancer: pooled analysis of eight prospective studies. J Natl Cancer Inst. 2012; 104(24): 1905-1916, doi: 10.1093/jnci/djs461, indexed in Pubmed: 23221879.

85. Qin LQ, Xu JY, Wang PY, et al. Soyfood intake in the prevention of breast cancer risk in women: a meta-analysis of observational epidemiological studies. J Nutr Sci Vitaminol (Tokyo). 2006; 52(6): 428-436, indexed in Pubmed: 17330506.

86. Trock BJ, Hilakivi-Clarke L, Clarke R. Meta-analysis of soy intake and breast cancer risk. J Natl Cancer Inst. 2006; 98(7): 459-471, doi: 10.1093/jnci/djj102, indexed in Pubmed: 16595782.

87. World Cancer Research Fund/American Institute for Cancer Research. Continuous Update Project Report. Food, nutrition, physical activity, and the prevention of breast cancer 2010 .

88. Travier N, Fonseca-Nunes A, Javierre C, et al. Effect of a diet and physical activity intervention on body weight and nutritional patterns in overweight and obese breast cancer survivors. Med Oncol. 2014; 31(1): 783, doi: 10.1007/s12032-013-0783-5, indexed in Pubmed: 24310809. 